\title{
Albin ESER
}

„Defences“ in war crime trials 


\title{
"DEFENCES" IN WAR CRIME TRIALS
}

\author{
By Albin Eser*
}

\section{INTRODUCTION - GENERAL OBSERVATIONS}

The first of many difficulties encountered in analyzing this topic concerns terminology. In addressing the subjects of obedience to superior order, necessity, self-defence, duress or coercion, consent of the victim, reprisals, military necessity or the "tu quoque-argument" and if, in addition, we were to expand our analysis to jurisdictional questions such as the application of the law, the statute of limitations, or the problem of international ne bis in idem, it would be almost impossible to subsume all these phenomena under just one term or concept. At least from the viewpoint of German doctrine, which differentiates between substantive elements of a crime and mere procedural requirements for its prosecution, and which, even on and within these two levels, distinguishes between justification, excuse, and other substantive or procedural prerequisites or bars to criminal liability and prosecution, it seems impossible to deal with all the aforementioned phenomena under the same rubric.

Therefore, there is no other solution but to resort to the English term "defences", which traditionally has been used to denote all grounds which, for one reason or another, hinder the sanctioning of an offence - despite the fact that the offence has fulfilled all definitional elements of a crime.

This notional broadness of "defences", however, is achieved at the price of a certain conceptual emptiness and lack of structure. Except for saying that the presence of a "defence" excludes punishability and/or prosecution of a crime, the term "defence" reveals nothing of the intrinsic rationales or the structural elements of the grounds for excluding punishability.

Furthermore, this deficiency is not only of theoretical importance, but, as will be demonstrated below, it also has a practical impact on the application of certain defences.

Professor Dr., Dr., h.c., M.C.J., Universität Freiburg i. Br. Direktor des Max-PlanckInstituts für ausländisches und internationales Strafrecht.

For assistance in preparing this contribution I wish to thank Christiane Nill; for refining my English version I am indebted to Emily Silverman. 
In view of these terminological deficiencies, it is not surprising that, from the doctrinal point of view as well, "defences" to international crimes must still be considered a vast terra incognita. This is perhaps best proven by the observation that literature in this area is rather scarce. ${ }^{1}$ Except for Jescheck's critical analysis of the Nuremberg trials (1954), Dinstein's dissertation on The Defence of 'Obedience to Superior Orders' in International Law (1965) and Bassiouni's chapter on "Defences and Exonerations" in his recent handbook on Crimes against Humanity in International Criminal Law (1992), one can find only occasional articles which hardly cover the whole range of problems.

The lack of jurisprudential literature in this field may at least be partly explained by the fact that, even in the development of a positive "Code of International Crimes", we are still stuck (to use a German expression) in "children's shoes". We are perhaps further along in developing a "Special Part" of "International Crimes", but we are still far from a "General Part", into which the special crimes would have to be embedded. ${ }^{2}$ Until such a "General Part" is developed, however, a well-principled and general definition of "defences" to an international "offence" can hardly be expected. ${ }^{3}$

If the pioneering work required to develop "defences" considerably exceeds that which is necessary for formulating "offences", this difficulty may partly be explained by certain psychological reservations toward defences of war crimes. By providing perpetrators of brutal crimes against humanity (such as the atrocious war crimes reported in the former Yugoslavia) with defences for their offences, we have effectively lent them a hand in finding grounds for excluding punishability or otherwise barring criminal prosecution. Although this antagonism is understandable on an emotional level, from the legal point of view war crimes may not be exempted from the general principles that are valid for "normal" every-day criminality. Just as a murderer may be justified by selfdefence, a rapist excused for insanity, or a policeman relieved from personal liability for suppressing resistance on "superior order", in war crime trials, too,

1 Laudable exceptions (the mentioning of which does not necessarily signify full agreement) are Y. Dinstein, The Defence of 'Obedience to Superior Orders' in International Law (1965); M. Ch. Bassiouni, Crimes against Humanity in International Criminal Law $397-469$ (1992).

2 See O. Triffterer, "Die völkerrechtlichen Verbrechen und das staatliche Strafrecht", 30 Zeitschrift für Rechtsvergleichung 83-129, 113 f. (1989); also M. Ch. Bassiouni \& C. L. Blakesly, "The Need for a General Part", 25 Vand. J. Transnat. L. 151-82, 154-75 (1992), H.H. Jescheck, "Gegenwärtiger Stand und Zukunftsaussichten der Entwurfsarbeiten auf dem Gebiet des Völkerstrafrechts", in Erinnerungsausgabe für Max Grünhut 47-60, 58 ff. (H. Kaufmann et al. eds., 1965).

3 A. Eser, "The Need for a General Part", in Commentaries on the International Law Commission's 1991 Draft Code of Crimes against the Peace and Security of Mankind 43-52 (M. Ch. Bassiouni ed., 1993). 
it cannot be excluded from the very outset that certain circumstances stand in the way of prosecution. If this is so, justice requires analysis and definition of the rationale and the limitations of such possible "defences".

This seems advisable, at the very least, for structural reasons in terms of the systematic comprehension of the crime. As we have discovered in studies on comprehending and comparing different notions of crime, the general elements and structural stages of crime - e.g., the German differentiation between the definitional elements of the crime, its unlawfulness and its blameworthiness (Tatbestandsmäßigkeit, Rechtswidrigkeit und Schuld) - may perhaps be incomprehensible without a clear understanding of the grounds on which the punishability of conduct, despite its fulfilment of all definitional elements of a prohibition (Tatbestand), will nevertheless be excluded. Thus, structural comparisons between different penal systems may perhaps become possible only by differentiating between defences with regard to their justificatory, excusatory or otherwise exonerating nature. ${ }^{4}$ Similarly, the search for the internal rationale and the extent of "defences" for international crimes (including war crimes) may perhaps prove to be a helpful key in structuring and defining a "General Part" of a truly comprehensive "Code of International Crimes".

Such a demanding and far-reaching goal is more than can be accomplished within the constraints of this article. Therefore, an introductory survey of those "defences" which are most likely to come into play in connection with war crime trials will be presented:

In doing so, I shall make two further restrictions:

- First, I shall only deal with substantive grounds of excluding criminal liability; procedural defences such as lack of jurisdiction or ne bis in idem will not be discussed.

- Second, this analysis will concentrate on the individual punishability of war criminals and will only occasionally allude to the collective responsibility of states (or heads of state) which is, to some extent, governed by other principles. These principles are generally more concerned with establishing criminal responsibility of a state (or its organs) rather than exempting it from responsibility.

4 See, in particular A. Eser, "Einführung", in 1 Rechtfertigung und EntschuldigungRechtsvergleichende Perspektiven, 1-8 (A. Eser \& G. P. Fletcher eds., 1987). See also A. Eser, "Die Unterscheidung von Rechtfertigung und Entschuldigung: ein Schlüsselproblem des Verbrechensbegriffs", in Criminal Law Theory in Transition 301-315, 313 (R. Lahti \& K. Nuotio eds., 1992). 


\section{MAIN DEFENCES}

\section{A. Obedience to Superior Order}

If I start with "obedience to superior order", it is mainly because this is - as already stated by Jescheck ${ }^{5}$ - the most frequently discussed as well as the most controversial defence in the area of war crimes. ${ }^{6}$ In the struggle for acceptance or rejection of this defence, several developments and positions, some quite contradictory, must be recognized.

- Prior to World War I, the problem of "superior order" did not play a big role. Until that time, the so-called "act of State-doctrine" reigned, according to which only States could be held liable, while the responsibility of individuals was basically irrelevant. ${ }^{7}$

- This attitude of ignoring the problem came to an end with World War I. Confronted with the highly disputed determination of soldiers as war criminals, Anglo-American military law tried to bar such trials by exempting soldiers from punishability insofar as their conduct had been masterminded by their government. ${ }^{8}$ This position was mainly backed by the theory of 'respondeat superior', substantially developed by Oppenheim, ${ }^{9}$ according to which, the subordinate, in case of a superior order, was given a sort of 'absolute defence'. ${ }^{10}$

- Contrary to this view, during and immediately following World War I, the so-called theory of "absolute liability" was already voiced, which demanded the punishment of soldiers as war criminals. ${ }^{11}$

- If, however, one did not want to go so far as to hold soldiers liable, the "manifest illegality principle" prevented soldiers, at least in cases of

5 H.H. Jescheck, Die Verantwortlichkeit der Staatsorgane nach Völkerstrafrecht 255 (1952).

6 Particularly informative to this defence are Dinstein, supra note 1; Dinstein, "International Criminal Law", 20 Is. L. Rev. 206-242 (1985), and L. C. Green, Superior Orders in National and International Law (1976); see also Bassiouni, supra note 1 , at 399-438.

7 See P. Fuhrmann, Der höhere Befehl als Rechtfertigung im Völkerrecht 24-30 (1963).

8 Art. 347 of the United States Rules of Land Warfare states: "Individuals of the armed forces will not be punished for these offences in case they are committed under the orders or sanction of their government or commanders. The commanders ordering the commission of such acts, or under whose authority they are committed by their troops, may be punished by the belligerent, into whose hands they fall."

9 L. Oppenheim, 2 International Law 264 f. (1912).

10 As to this terminology, cf. infra Sec. III.2.

11 See Fuhrmann, supra note 7, at 43. 
obvious illegal orders, from resorting to "superior order" as a defence. ${ }^{12}$

Between these extremes, a middle of the road position started to develop after World War II. At the beginning of the war, neither valid international treaty law governing these questions, nor customary law on "superior order" existed. ${ }^{13}$ It was inevitable that with the start of the war crime trials at Nuremberg and Tokyo the problems of superior order would arise. The Nuremberg Tribunal neither fully recognized nor fully rejected the idea of superior order, but instead, paved the way for a new approach. Although not recognized as a full defence, obedience to superior order was at least to be treated as grounds for mitigation "if the Tribunal determines that justice so requires". ${ }^{14}$ Consequently a soldier could be completely freed from personal responsibility only by a fully independent defence or if he performed an act in the execution of an order under duress, meaning that, above and beyond the order, the subordinate soldier had to rely on additional pardonable circumstances. Thus, by taking into consideration mitigation in cases of superior order, the Charter of the International Military Tribunal for the first time in the history of international law positively and expressly took notice of this aspect. This formal recognition has recently been reaffirmed by the Statute for an International Tribunal for the former Yugoslavia. ${ }^{15}$

Whereas this provision in the treaties does not reveal why only mitigation and not a full defence is conceded, Dinstein seems to provide an explanation by his theory based on mens rea. Though obedience may not be a "defence per se" the subordinate may deserve mitigation due to lack of criminal awareness, whereby lack of mens rea may be acknowledged only in cases of "compulsion" or "mistake". 16

After this brief review of historical background, the four most important positions regarding superior order may now be critically surveyed.

12 Cf. infra II A. 3, esp. at note 31.

13 See Fuhrmann, supra note 7, at 65.

14 As phrased in Art. 8 of the Charter of the International Military Tribunal (IMT): "The fact that the Defendant acted pursuant to order of his Government or of a superior shall not free him from responsibility, but may be considered in mitigation of punishment, if the Tribunal determines that justice so requires."

15 Cf. Art. 7 No. 4 of the Statute for the "International Tribunal to prosecute persons responsible for various violations of international humanitarian law committed in the territory of the former Yugoslavia since 1991".

16 Cf. the presentation by Dinstein, Is. L. Rev., supra note 6, at 237. 


\section{The One Extreme: Obedience to Superior Order as Defence}

In order to explain why the theory of respondeat superior ${ }^{17}$ should provide a full defence, three reasons are generally given, ${ }^{18}$ none of which, however, is really convincing:

If one is not content simply to rely on the binding effect of an order, ${ }^{19}$ the primacy of national law may be offered as an argument: Since domestic law requires obedience from its soldiers, and as it may even be in the interest of international law to maintain discipline and order in a national army, it appears insupportable for international law to punish a soldier for performing a national duty. ${ }^{20}$ Yet, as convincingly counter-argued by Dinstein, the alleged contradiction between international law and the primacy of the national duty is not a real one. Since the prohibition of war crimes is founded on and by international law, corresponding exceptions from sanctioning can only be made by international law. ${ }^{21}$ Otherwise, any international prohibition of war crimes could be undermined by national orders.

back to Oppenheim: see supra note 9.

18 See J. D. Brownlie, "Superior Orders - Time for a New Realism?", The Crim. L. Rev. 396-411, 397 (1989). See also Dinstein, supra note 1, at 38 (though Dinstein himself does not necessarily take this view).

19 See the references by H.H. Jescheck, supra note 5, at 259.

20 Cf. Oppenheim, supra note 9, at 343. Cf. also the case-law, which on the basis of the former version of Art. 443 of the British Manual of Military Law also started from the absolute non-liability of the subordinate soldier, at Brownlie, supra note 18, at 398: "Members of the armed forces who commit such violations of the recognized rules of warfare as are ordered by their Government, or by their commander, are not war criminals and cannot therefore be punished by the enemy. He may punish the officials or commanders responsible for such orders, if they fall into his hands...." In Jescheck's presentation, this defence, though not clearly recognizable from its wording, is understood as a ground for excluding blameworthiness (SchuldausschlieBungsgrund). The subsequent alteration of Art. 443 of the British Manual made the responsibility of the subordinate conditional upon the lawfulness of the order. If the order was unlawful, the inferior could not escape responsibility: "The question, however, is governed by the major principle that members of the armed forces are bound to obey lawful orders only and that they cannot escape liability if, in obedience to a command, they commit acts which both violate unchallenged rules of warfare and outrage the general sentiment of humanity." A similar alteration was made to Art. 347 of the United States Rules of Land Warfare, according to which the responsibility depends on whether the soldier's belief in the order was acceptable. For more details cf. Jescheck, supra note 5, at 260.

21 Dinstein, supra note 1 , at 42. 
- Equally unconvincing is the claim of the subjective impossibility of refusing an order, based upon the reasoning that the soldier, due to being an integral part of a tight and severe military discipline, is somehow a mere tool in the hands of an overwhelming power. ${ }^{22}$ The consequence of such argumentation is that the soldier is degraded to a blindly obeying machine with no personal responsibility. ${ }^{23}$ However, facts belie the widespread assumption that the refusal to obey an order to commit a war crime necessarily results in punishment of the disobedient subordinate. ${ }^{24}$ Perhaps even more important are the political as well as the psycho-social counterproductive side effects of endorsing (by treating obedience as an absolute defence) such hierarchical 'order' mentality. Acknowledging this defence could result in cases where superiors evade their own responsibility - e.g., by suicide like Hitler or Himmler, or by fleeing to a safe foreign haven were war crimes still remain unsanctioned ${ }^{25}$ because of the lack of international solidarity in combatting international crimes.

- If one wants to avoid this frustrating consequence by conceding a defence for obedience to a superior order only to those acting in good faith, ${ }^{26}$ one is merely shifting the problem but not solving it. The only difference is that in this line of argument it is not the obedience which excludes punishability, but the error with regard to the illegality of the order. Similarly, this applies to cases where the subordinate, though aware of its unlawfulness, executes the order because of the threat of being shot in case of refusal. In this situation, too, it is not the order, but the coercion which provides the defence. ${ }^{27}$

22 M. Belgion, Victors Justice 143 (1949).

23 See D. H. M. Johnson, "The Defence of Superior Orders", Australian Y.B. of Int. L. 291-314, 299 (1985).

24 To give one example: H. Jäger, Verbrechen unter totalitärer Herrschaft, Studien zur national-sozialistischen Gewaltkriminalität 158 (1967), found that in none of the some 103 cases in which Nazi functionaries refused to carry out orders to kill was the refusal to obey punished. See also L. Gelberg, "Die Nürnberger Prinzipien und das modeme Völkerrecht", Demokratie und Recht 177-87, 183 (1978). For a different view. see A. von Knieriem, Nürnberg: Rechtliche und menschliche Probleme 275 (1953) who saw a danger to the subordinates in the mere fact that the orders concerned presumably stemmed ultimately from Hitler himself.

25 Gelberg, supra note 24, at 181; see also H. Laternser, "Looking Back at the Nuremberg Trials with Special Consideration of the Process against Military Leaders", Whittier $L$. Rev. 557-80, 577 (1986).

26 As suggested by B. V. A. Röling, "Criminal Responsibility for Violations of the Laws of War", 12 Revue belge de droit international 8-26, 18 (1976).

27 To be understood in the same way is Jescheck, supra note 5 , at 255 , for whom a strict classification of superior order in the catalogue of 'SchuldausschlieBungsgrund' 


\section{The Other Extreme: "Absolute Liability" Despite Acting on Superior Order}

Diametrically opposed to the theory of respondeat superior is the doctrine of "absolute liability", according to which - superior order is neither an independent defence nor may it even be considered as an element of other defences. ${ }^{28}$

- This position is partly based on the argument that soldiers from the very outset are only duty-bound to execute lawful orders in order that obedience may never be proffered as a defence. ${ }^{29}$ This approach, however, may not sufficiently take into account the possible coerciveness of the hierarchial chain of command of which the soldier is a part.

- Similarly, the argument that personal responsibility would gradually be passed along to the supreme commander if every subordinate were allowed to rely on superior order, with the possible exception of liability pertaining to an original order, ${ }^{30}$ is convincing only if obedience to an order excluded punishability per se and unconditionally.

- In addition, strict rejection of any reliance on an order suffers from focusing too globally and superficially on the moment of the "order as such", without questioning its lawful or unlawful purpose and without taking into consideration the subjective good or bad faith of the party to whom the order is addressed.

(ground for excluding blameworthiness) is "not possible because according to the factual situation aspects of mistake of law or conflicts of interests could be prominent".

28 H. H. Bellot, A Permanent International Criminal Court 73-78 (1922); G. Brand, "The War Crimes Trials and the Laws of War", 26 Brit. Y.B. Int'l. L. 414-27, 416 (1949); A. Goodhardt, "Questions and Answers Concerning the Nuremberg Trials", Int'l. L. $Q$. 525-31, 527 (1947); C. Phillipson, International Law and the Great War 260 (1915); G. Schwarzenberger, "The Judgement of Nuremberg", Y.B. World Affs. 94-124, 117 (1948); see also the references by Dinstein, supra note 1, at 68, n. 205.

29 Bellot, supra note 28, at 73-78; see also the reference by H. G. Schwenk, "Gesetzgeberische Konsequenzen aus den Verboten der Zusatzprotokolle", Neue Zeitschrift für Wehrrecht 199-212, 207-211 (1978) for a discussion of the soldier's role today.

30 Phillipson, supra note 28, at 260. 


\section{Distinctions According to "Manifest Ilegality" and/or Mens Rea}

Distinctions such as those just mentioned, seem to be applied to an increasing degree in order to avoid the contrary extremes of orders as complete defence, on the one hand, or totally ignoring them, on the other.

- One of these middle of the road approaches, i.e., the "manifest illegality" principle, is to preclude reliance on a superior order as a defence, at least in cases where the unlawfulness of the order is obvious. ${ }^{31}$

- The subjective element implied in this approach becomes even more apparent in Dinstein's mens rea approach in which the awareness (or rather the lack of awareness) of unlawfulness due to mistake of fact or law is of particular significance. ${ }^{32}$

- Despite these common features, an essential difference remains: Whereas, according to the "manifest illegality principle" the execution of an order which was not obviously illegal, may constitute an independent defence, the "mens rea-approach" seems to regard the moment of the order, if it considers it at all, only as a component of another defence, such as mistake or compulsion. ${ }^{33}$

Without presenting a detailed explanation here, I suggest that the proper solution can be found in distinctions such as those mentioned above. If, however, methods of reasoning leading to this result quite often appear to be anything but clear and stringent, this may be caused by a failure to distinguish between justification or excuse or other - perhaps politically motivated grounds for excluding criminal prosecution. Since certain authors seem to be afraid that conceding a defence would be interpreted as endorsement of an unlawful order, they feel forced to refuse reliance on an order even in cases where the subordinate performed it in good faith. If, however, they were aware that by rejecting justification and merely conceding an excuse, the

31 See M. Greenspan, The Modern Law of Land Warfare 409 (1959); H.H. Jescheck, "Befehl und Gehorsam in der Bundeswehr", in Bundeswehr und Recht 63-91, 63 f. (H.H. Jescheck, et al. eds., 1965); N. Keijzer, Military Obedience 169 (1978), G. Dahm, 1 Lehrbuch des Völkerrechts, 311 (1961). Apparently in the same sense Th. Vogler, "The Defense of 'Superior Order' in international criminal law", in 1 A Treatise on International Criminal Law: Crimes and Punishment 619-34, 634 (M. Ch. Bassiouni \& V. P. Nanda eds., 1973).

32 See Dinstein, supra note 1, at 76, 87; also in Dinstein, supra note 6, at 233.

33 Bassiouni's "command-responsibility theory" seems to run along the same line when opposing the full rejection of this defence on the one hand but recognizing it, at least under certain circumstances, on the other. See Bassiouni, supra note 1, at 437. 
disapproval of an order and its execution remains intact, certain alleged contradictions might appear to be reconcilable. ${ }^{34}$

\section{Obedience to Superior Order as Ground for Mitigation}

As long as superior order is not recognized as a full or at least self-sufficient defence, the widespread opinion seems to be that the obedience of the subordinate may at least be considered as a ground for mitigation. ${ }^{35}$ This position, as already mentioned, was recognized for the first time by the Charter of the International Military Tribunal at Nuremberg and just recently reaffirmed by the Statute of the International Yugoslavia Tribunal. To date, however, neither the prerequisites for mitigation nor the possible degree of reduction of the punishment have been established, but have apparently been left to the discretion of the Tribunal, which under Article 8 of the Charter provides that mitigation may be considered "if the Tribunal determines that justice so requires". ${ }^{36}$ If this discretion is not to be absolute but governed somehow by certain criteria, it is necessary to identify the reasons and factors for which obedience to a superior order can be denied full exclusion of punishability, on the one hand, but conceded at least mitigating influence, on the other. These rationales, each of which may also lead to divergent consequences, may be quite varied:

- If the lack of mens rea rather than the obedience to an order is considered to be decisive, it is quite obvious that the order cannot be granted more weight than other guilt-oriented mitigating factors. ${ }^{37}$

- or if a full defence is rejected because a crime committed on order would otherwise remain completely unsanctioned, ${ }^{38}$ the mitigation must

34 For removal of similar inconsistencies by distinguishing between justification and excuse, see A. Eser, "A Key Issue in the Concept of Crime", in I Rechtfertigung und Entschuldigung - Rechtsvergleichende Perspektiven 17-65, 37 (A. Eser \& G. P. Fletcher eds., 1987).

35 Cf. Dinstein, supra note 1, at 88 ff.; H. Lauterpacht, 2 International Law 302 (H. Lauterpacht \& L. Oppenheim eds., 1952); L. C. Green, "Superior Orders and the Reasonable Man", 8 Can. Y.B. Int'l L. 61-103, 103 (1970); Johnson, supra note 23, at 307; Gelberg, supra note 24, at. 181; P. Guggenheim, 1 Lehrbuch des Völkerrechts 551 (1948); Jescheck, supra note 5, at 268; see also references by Bassiouni, supra note 1 , at 415 .

37 See Dinstein, supra note 1 , at 88.

38 In the same direction Green, supra note 35, at 103; see also the references by Johnson, supra note 23, at 307; Bassiouni, supra note 1, at 415; Gelberg, supra note 24, at 181. 
be structured in such a way that belief in law and justice is not destroyed;

- or if neither blind obedience is to be rewarded nor pressure on a subordinate completely ignored, ${ }^{39}$ then mitigation would have to be measured according to the kind and degree of the coercive situation to which the soldier is exposed.

As demonstrated by these few examples, by conceding mitigation, the problem underlying obedience to a superior order is merely shifted rather than solved.

\section{B. Necessity}

In the same way that necessity can justify a prohibited act in domestic law, in international law, too, necessity is, in principle, recognized as a defence. ${ }^{40}$ Beyond this very general statement, however, it is difficult to gain a clear view of the various situations and conditions in which necessity may exclude punishability.

At any rate, it seems advisable to distinguish between "necessity of the State" ("völkerrechtlicher Notstand") and "individual necessity". 41

1. If the State is in necessity, because its existence is threatened by a clear and present danger, the State, relying on its "right to self-preservation", may act to free itself from the threat. ${ }^{42}$ In this case, its supreme organs are entitled to order the necessary measures. Therefore, the actions of the executing functionaries are accordingly justified. ${ }^{43}$ Examples of these types of measures include the sinking of ships or the destruction

39 See D. de Vabres, Traité de droit criminel et de législation pénale comparée 241 (1947), but also W. J. Garner, International Law and the World War 484 (1920).

40

See I. Seidl-Hohenveldern, Völkerrecht 370 Rn. 1674-80 (7th ed. 1992); A. Verdross \& B. Simma, Universelles Völkerrecht 869 (3rd ed., 1984); G. Gorning, "Die Verantwortlichkeit politischer Funktionsträger nach völkerrechtlichem Strafrecht", 46 Neue Justiz 4-14, 10 (1992).

41 In the same sense, Art. 32 of the International Law Commission's Draft for an International Court: " 1 . The wrongfulness of an act of a state not in conformity with an international obligation of that state is precluded if the author of the conduct which constitutes the act of that state had no other means, in a situation of extreme distress, of saving his life or that of persons entrusted to his care. 2. Paragraph 1 shall not apply if the state in question has contributed to the occurrence of the situation of extreme distress or if the conduct in question was likely to create a comparable or greater peril." See also Verdross \& Simma, supra note 40, at 871.

See Jescheck, supra note 5, at 220.

43 See ibid., 222. 
of underwater cables. ${ }^{44}$ This type of necessity, however, was not a basis for the NS-ordered genocide in which SS troops were involved, nor can it be invoked with regard to war cruelties in the former Yugoslavia.

2. Therefore, perhaps only personal necessity can be considered a defence. In this regard, however, it is very difficult to imagine a factual situation in which a soldier is able to avert personal danger by simply committing a war crime - unless he is pressed by his comrades to participate in a war crime. In such cases, however, "duress" or "compulsion" will apply, and not necessity, thereby raising 45 defences which have to be dealt with on their own merits.

However, it is worthwhile to mention that the Anglo-American approach to necessity appears somehow less liberal, ${ }^{46}$ an attitude which again seems to be influenced by the failure to distinguish between justification and excuse. If this distinction were properly recognized, appropriate and well-principled differentiations might also prove easier in this area as well.

\section{Self-defence}

Self-defence is similar to necessity in that it is difficult to imagine a factual scenario where the need to avert an attack justifies an act of self-defence in the form of a war crime. Certainly the idea of self-defence is not foreign to international criminal law. The "natural right to individual and collective selfdefence" is expressly recognized under Article 51 of the UN Charter, as long as the Security Council does not take the necessary measures to preserve world peace and international safety. Therefore, it can at least be considered misleading when Bassiouni, in his broad interpretation of international crime in his handbook on crimes against humanity, does not deem self-defence worthy of discussion because it is a "personal defence, which arises under the criminal law of the enforcing State". 47

44 See ibid., Verdross \& Simma, supra note 40 , at 870.

$45 C f$. to this distinction in German criminal law H.J. Hirsch, "Prenote to $\S 35$ " in Strafgesetzbuch - Leipziger Kommentar (H.H. Jescheck, et al. eds., 10th ed., 1985).

46 See Dinstein, Is. L. Rev., supra note 6, at 234; also "Criminal Law", 15 American Jurisprudence, § 318 Coercion or Command 16 (1943). See also D. Linnan, "Iran Airflight 655 and Beyond: Free Passage, Mistaken Self-Defence and State Responsibility", 16 Yale J. Int'l L. 245-389, 340 (1991), referring to the rejection of necessity in a case in which prisoners were killed to avoid detection when encircled by the enemy; see also Knieriem, supra note 24, at 279.

47 Bassiouni, supra note 1 , at 398. 
Nevertheless, this point of view may prove to be correct in so far as the right to self-defence, recognized by the UN Charter, is primarily conceded to the State under attack. Therefore, this defence may be available to the individual soldier, if at all, only in a derivative manner and, in addition, hardly conceivable if the act of self-defence constituted a war crime.

This narrow reach of individual self-defence in a state under attack may also explain why there is almost no literature concerning the question of selfdefence in the area of war crimes.

\section{Compulsion - Duress - Coercion}

Similar to the defences dealt with so far, which are clouded by conceptual vagueness, the defences commonly handled, such as necessity, compulsion, duress and coercion, are even more difficult to resolve since there is still no uniform terminology. ${ }^{48}$ Whereas Bassiouni sees "coercion" and "duress" as closely connected to "obedience to superior order", but not to "necessity", ${ }^{49}$ Dinstein deems it possible, by following the International Military Tribunal of Nuremberg, to regard "compulsion" as the general term, that can be subdivided into the more specific instances of "duress under threat" and "necessity to avoid fatal results in other circumstances". 50

Instead of adopting either of these approaches, it seems preferable to emulate an old distinction in German law, that seems to have been preserved in the international law literature in the German language, that distinguishes between states of necessity or pressure that are caused by other human beings, as in cases of coercion, compulsion or duress (Nötigungsnotstand), and those resulting from natural causes or dangers not caused by human beings, as perhaps fairly described by necessity (Notstand)..$^{51}$

Current opinion considering the prerequisites for the magnitude of a defence of compulsion in the aforementioned sense is anything but easy to grasp. Common law, for instance, would excuse all activities committed in a special situation of duress, except for the taking of innocent life, in which case, even for the sake of rescuing his own life, the perpetrator may never rely upon

See Dinstein, Is. L. Rev., supra note 6, at 234. As he is one of few who has devoted more than passing attention to these issues, mention should be made of the case study by A. L. Dienstag, "Fedorenko v. United States: War Crimes, the Defense of Duress, and American Nationality Law", 82 Colum. L. Rev. 120-83 (1982).

49 Bassiouni, supra note 1 , at 439.

50 Dinstein, Is., L. Rev., supra note 6, at 233.

51 For a similar use of the terms, see Bassiouni who, however, apparently uses the term "compulsion" as a generic term for coercion and duress. Bassiouni, supra note 1, at 439. 
duress as a defence. ${ }^{52}$ To some extent, the rejection of such a defence is also based on the assumption that in most cases a war criminal who was threatened with the unpleasant consequence of the failure to obey an order would have had other ways of evading the threatened harm. ${ }^{53}$ Furthermore, it is feared that by recognizing such defences, subordinates would be able to exonerate themselves, and only "the very apex of the command chain" 54 could be left to bear responsibility, if, indeed, one could get hold of them at all.

However, as understandable as these arguments may be, we must keep in mind that the refusal to exempt the coerced subordinate from punishment does not necessarily mean that the ordered war crime would not be committed, since the superior could still look, and probably find, a more obedient subordinate. Still more urgent is the normative proposition that it might be morally overburdensome to demand suicidal heroism from the average soldier in the face of otherwise being punished.

The doctrine and practice of international law obviously have significant difficulties in solving the problem of duress, and once again, the lack of distinction between justification and mere excuse seems to play a detrimental role. Perhaps the path to appropriate solutions would be easier to find if one were aware that the mere excusing by the commission of a crime under duress is not tantamount to an approval of the unlawful act as such.

\section{E. Conflict of Interests}

During the Nuremberg trials, it was quite common for military commanders to defend themselves by referring to a conflict of interests: Patriotic duty required them to stay at their posts, and in order to prevent the worst, they bowed to higher orders. Astonishingly, this resort to conflict of interests is dealt with in more depth only by Jescheck's study of the Nuremberg trials (under the heading of "Pflichtenkollision") 55 whereas in other listings of "defences and exonerations" (as for instance by Bassiouni) this topic is not expressly addressed. Perhaps this silence in the non-German literature of international crimes can be explained by the fact that the Nuremberg judgments bluntly rejected conflict of interests as a defence by reasoning that remaining in office conveyed moral support of Hitler's violent regime. This was more detrimental

52 See Dienstag, supra note 48 , at 137 , with references to case-law.

53 Ibid., 149.

54 Ibid., 151.

55 Jescheck, supra note 5, at $395 \mathrm{f}$. 
than the aid, possibly made available by these officers to persecuted people, was beneficial. 56

It is, of course, open to question whether conflict of interests as a defence should be rejected out of hand, even as a mere ground for excluding punishability beyond justification and excuse, as was then conceded by the Supreme Court for the British Zone in certain cases of the so-called "euthanasia actions" in NS-killing-camps. ${ }^{57}$ However, the answer to this question largely depends upon the meaning of conflict of interests, for which a generally accepted definition has yet to be agreed upon. ${ }^{58}$

Nevertheless, I wonder whether conflict of interests should be totally ignored in war crime trials in cases where a military leader finds himself faced by a genuine moral dilemma from which, according to the principle of "lesser evil", he sees no other way out. Only truly extreme situations, however, should be eligible for such a defence.

\section{F. Consent of the Victim}

Consent of the victim, which in the scope of "normal criminality" is quite a common defence, is hardly discussed in the literature of war crimes (again, with the rare exception of Jescheck), despite the fact that the Nuremberg judges were frequently faced with the invocation of this defence. ${ }^{59}$

Briefly, their position was as follows:

1. As far as the lawfulness of "voluntary" employment of war prisoners in the armament industry was concerned, reliance of the defendants upon the consent of the prisoners was rejected. As there was no legal basis for the employment contracts, it must be assumed that the labour was forced and without consent. 60

56 See ibid., 394, esp. 398.

571 OGHSt (Entscheidungen des Obersten Gerichts für die britische Zone) 321, 335 (1949); 2 OGHSt 117 ff.; 126 (1949). A divergent view was taken by the Federal Supreme Court (Bundesgerichtshof), Nene Juristische Wochenschrift 513 f. (1953), which provided for possible exoneration on the basis of a particularly diligently scrutinized mistake of law. $C f$. also, the notes to these cases by H. Welzel, Monatsschrift für Deutsches Recht 375 (1949), and E. Schmidt, Silddeutsche Juristenzeitung 568-70 (1949).

58 For more details and references see T. Lenckner, "Prenotes $71-78$ to $\S 32$ ", Kommentar zllm StGB (A. Schönke \& H. Schröder eds., 24th ed., 1991).

59 See Jescheck, supra note 5, at 335 f.; see also Knieriem, supra note 24, at 309.

60 See Jescheck, supra note 5, at 335 to the "Milch- und IG-Farben" case. 
2. Use of war prisoners in military operations, however, was deemed to violate international law only in cases of "force, threats or duress", but not when services had been agreed to voluntarily by war prisoners. This reasoning, as was applied by the Nuremberg Court in the "Wilhelmstraßen-Proceeding", has been criticized by Jescheck as quite dangerous, since it does not pay sufficient attention to the pressure inherent in war captivity, particularly when the living conditions are close to the subsistence level. ${ }^{61}$

3. To speak of true volunteerism is similarly difficult, if not impossible, in cases such as the Nuremberg physicians' trials where captives had "volunteered" to be subjects in medical experiments. Even when victims on their own initiative signaled their readiness to participate in certain experimental procedures (such as the sterilization of so-called "half-Jews"), they did so only in the hope, that in this way, they would perhaps escape transportation to a concentration camp. Under these circumstances, it would be utter cynicism to speak of voluntary participation in a medical experiment. ${ }^{62}$

4. The cynicism would hardly be less offensive if Serbian soldiers attempted to defend their raping of Bosnian women by claiming that women who did not forcefully resist had implicitly given their consent.

As should be clear from these few examples, there is very little room indeed for consent as a defence in war crime trials, for when a victim co-operates in an attempt to avoid a worse fate, there can be no talk of volunteerism, which is the core element of consent.

\section{G. Mistake of Law and Fact}

This defence is of particular importance for those positions which reject "superior order" as an independent defence and resort instead to the principle of mens rea (as proposed by Dinstein). ${ }^{63}$

However, with regard to mistake, too, certain distinctions should be remembered.

61 Ibid., 336.

62 Therefore rejecting with good cause also Knieriem, supra note 24, at 309.

63 Cf. supra II A.I with footnote 32. Bassiouni, too, points to "mistake of law or fact" as possible defences but refers only to mistake of law in chapter 1 ("emergence as an international crime"), however, without providing more precision. See Bassiouni, supra note 1 , at 398 . 
1. Apparently only mistake of fact is generally recognized as a defence in international law and practice, whereas mistake of law is still deemed irrelevant in accordance with the old maxim of error iuris (criminalis) nocet. ${ }^{64}$ Nevertheless, there are at least some exceptions for cases where the perpetrator lacked mens rea due to a so-called "honest error".

2. Along this line, Jescheck proposes that an error as to the terms and rules of international war law be recognized, at least as an excuse. ${ }^{65}$ In fact, the danger of committing such an error is particularly great for military leaders who must act even when burdened by extraordinary responsibility and serious emotional strain. According to Jescheck, such an error should be taken into consideration in so far as it does not contradict sound perceptions of law and justice, i.e., does not show signs of blindness to the law. The Nuremberg judges, however, were not willing to make any concessions with regard to errors concerning terms and rules of the international law of war. This position can perhaps be explained by the greater reluctance with which the common law still approaches the defence of "mistake of law", even in everyday crimes. ${ }^{66}$

And indeed, keeping in mind the degree to which so-called "war morals" are being brutalized in some military conflicts of our time, it seems strongly advisable to make a defence by mistake of law as difficult as possible in order to avoid any promotion of scrupulousness in this area.

\section{H. Reprisals}

With regard to the category of reprisals, we are on comparatively safe ground since international law, in principle, recognizes retributive measures against another State or its nationals, at least in so far as the measures are intended to force the adversary to conduct himself according to international law. ${ }^{67}$ Within this scope, reprisals are not restricted to destruction of property. Even homicide may be justified so long as proportionality between the cause and effect of the reprisal is present. This required proportionality was not present,

64 Jescheck, supra note 5, at 378.

65 Ibid., 383.

66 See A. T. Smith, "Error and Mistake of Law in Anglo-American Criminal Law", in 2 Rechtfertigung und Entschuldigung - Rechtsvergleichende Perspektiven, 1075-1124 (A. Eser \& G. P. Fletcher eds., 1988); J. Kaplan, "Mistake of Law", ibid., 1125-48.

67 With regard to confirmations by the IMT of Nuremberg see Jescheck, supra note 5, at 333; also Seidl-Hohenveldern, supra note 40, at 393, n. 1776; Bassiouni, supra note 1, at 447 . 
however, in the so-called Einsatzgruppen-Fall, where as reprisal for the killing of 21 German soldiers, 859 out of 2,100 Jews were sent to death. ${ }^{68}$

The unacceptability of such excesses is certainly beyond any doubt. But even beyond that, the question arises of whether the right to reprisals should not be still more restricted since in cases where revenge plays a role, reprisals are always subject to abuse. Perhaps reprisals should not be allowed for mere retribution, but only as a means of forcing the adversary to comply with the rules of international law.

\section{Tu Quoque Argument}

Closely related to reprisals is the tu quoque argument, which - either quite simply according to the motto "you too", or perhaps by relying on the authority of the Old Testament's "eye for eye, tooth for tooth" - seems to allow the commission of an international crime simply because of the fact that the adversary is behaving in the same (reprehensible) way.

However, these analogies are not at all cogent. Whereas Biblical retribution is directed toward the perpetrator of the original damage and reprisals aspire to compel proper international conduct upon the counterpart, the tu quoque argument allows a party, $\mathrm{A}$, to justify wrongs it has committed against a third party, B, by comparing its actions to the unlawful conduct of B against another third party, C. ${ }^{69}$

In the Nuremberg trials, the Tribunal rejected references of German defendants to allied violations of war law simply by maintaining that these breaches of international law were not comparable to the war crimes committed by the Nazi regime. ${ }^{70}$

However, even if the war crimes committed on both sides were comparable, whether the tu quoque argument should lead to mitigation as was, in principle, conceded in the Nuremberg trials, ${ }^{71}$ not to mention full exoneration from punishability or even justification - is debatable, for by opening this door, even if just a crack, the way is paved for an ever-increasing escalation of competing crimes. It is a relief, therefore, that the tu quoque argument is being met by growing opposition. ${ }^{72}$

68 Bassiouni, ibid., 458.

69 See ibid., 460.

70 See Jescheck, supra note 5, at 411; Gelberg, supra note 24, at 184.

71 See Jescheck, supra note 5, at 412 referring to the "II. Generals-Urteil".

72 See also Gelberg, supra note 24, at 184; R. K. Woetzel, The Nuremberg Trials in International Law 120 (1962). 


\section{J. Military Necessity}

We must now consider the case where a State violates another state's or its citizens' rights and interests because of so-called "military necessity" - a situation different from reprisals, which are justifiable only if preceded by a breach of international law by the adversary State. ${ }^{73}$

The defence of military necessity is particularly important when areas have been devastated. As was stated in the Charter of the Nuremberg Tribunal and reaffirmed in more detail by the International Court for the former Yugoslavia, even extensive destruction and appropriation of property, ${ }^{74}$ as well as "wanton destruction of cities, towns or villages, or devastation" may be "justified by military necessity". ${ }^{75}$ This defence, however, extends neither to killing of civilians nor to their deportation to concentration camps - actions that are never justified. ${ }^{76}$

Even within its narrow scope, this defence, too, is not without hazards since allowing reference to "military necessity" may lead to the erroneous but tempting conclusion that a State at war may do anything necessary to achieve victory.

\section{K. Immunity of Heads of State}

Finally, we must address, at least briefly, the immunity of heads of State which may also be invoked as a defence.

At first glance, this sort of defence seems quite plausible since, at least in times of peace, the head of State of a foreign power, in principle, is granted immunity. ${ }^{77}$ If this protection against criminal prosecution were to extend to war crimes, however, the supreme commander of the State would be relieved of responsibility while the performers of the command would be held criminally liable. This scenario seems to be the classical proof of the unhappy experience of the public at large: "They hang the minor figures, but let the major ones go".

Although it would be unrealistic to deny that international practice is in fact proceeding along this cynical line, the Charter of the Nuremberg Tribunals

73 See Knieriem, supra note 24, at 322.

74 Art. 2 (d) of the Statute of the International Tribunal for Yugoslavia.

75 Art. 3 (b) ibid. Cf. also Art. 5 (b), ibid. of the Nuremberg-IMT-Charter.

76 See Jescheck, supra note 5, at 331, referring to the "II. Generals-Urteil".

77 See Seidl-Hohenveldern, supra note 40, at 312, n. 1485; see also Bassiouni, supra note 1 , at $465 ;$ G. Schwarzenberger, supra note 28 , at 508 . 
expressly denied the immunity of heads of State in times of war. ${ }^{78}$ This position was recently reaffimed by the International Court for the former Yugoslavia. ${ }^{79}$

Yet, as a matter of fact, the only instance so far in which the ruler of a country was denied immunity and prosecuted by another country was the case of General Noriega; ${ }^{80}$ with regard to similar efforts vis-à-vis Saddam Hussein, words have not yet been followed by actions. ${ }^{81}$

What might be grounds for hope in the future is the fact that the ILC's Draft Code of International Crimes of 1991 does not discharge heads of State or government from criminal responsibility, ${ }^{82}$ and that, meanwhile, the aforementioned Yugoslavia Tribunal has been installed. ${ }^{83}$ However, as long as trials cannot be conducted, and judgments rendered in the absence of the accused, ${ }^{84}$ the prospects for a truly efficient prosecution of those principally responsible for war crimes in the Yugoslavian battles are extremely poor.

\section{SUMMARY - OUTLOOK}

Though this survey neither pretends to be comprehensive nor to have addressed all problems involved, I will allow myself to make some concluding observations:

1. As to the genesis of "defences" to war crimes, it seems worthy of mention that the Nuremberg Trials have served as a milestone not only

78 Art. 7 IMT of Nuremberg states: "Neither the official position, at any time, of an accused, nor the fact that an accused acted pursuant to order of his government or of a superior shall, of itself, be sufficient to free such accused from responsibility for any crime with which he is charged, but such circumstances may be considered in mitigation of punishment if the Tribunal determines that justice so requires."

79 Art. $8 \mathrm{III}$.

80 Cf. United States v. Noriega, 808 F. Supp. 791 (S. D. Fla. 1992).

$81 C f$. Hearing before the Subcommittee on International Law, Immigration, and Refugees of the Committee of the Judiciary, House of Representatives, 102nd Congress, 1st Sess. 13 March 1991, Serial No. 3.

82 See Art. 13 Draft Code of Crimes against the Peace and Security of Mankind of the International Law Commission: "The official position of an individual who commits a crime against peace and security of mankind, and particularly the fact that he acts as head of State or Government, does not relieve him of criminal responsibility."

83 For a German perspective on this court see C. Hollweg, "Das neue Internationale Tribunal der UNO und der Jugoslawienkonflikt", 48 Juristen Zeitung 980-89 (1993) with more references.

84 Leaving open here whether criminal procedures and judgments in absentia might be admissible at all: opposing, see ibid., n. 68. 
for the establishment of international "offences" but also for conceding "defences" by which punishability may be excluded. The law created on this occasion was, to be sure, occupational law - restricted to Germany and other defeated countries and is not considered "international law" in its true sense. Nevertheless, the Nuremberg Trials, in connection with the Charter of the Tribunal, provided a testing ground for various defence strategies, some of which have been more successful than others. It is deplorable that, except for the analysis of these trials by Jescheck, no other studies of these questions, neither in the literature nor in case-law, have followed. Even the Draft Code of Crimes against the Peace and the Security of Mankind of the International Law Commission of 1991 leaves much to be desired, especially with regard to the lack of clearly formulated defences. ${ }^{85}$ The same is true for the Statute of the International Tribunal of 1993 for former Yugoslavia, where "military necessity" as a ground of justification (Article 2d, 3b) and "superior order" as a ground for mitigation (Article 7) are the only defences mentioned.

2. With regard to their exonerating reach and effect, the defences currently in the limelight can be divided into three groups:

- A first group could be characterized as absolute defences which for whatever reason - are by tradition and common opinion given the effect of excluding punishability. This applies to necessity of the State and its self-defence, reprisals compelling conduct in accordance with international law, devastation justified by military necessity, mistake of fact, and duress. The common denominator of these defences is that they originate in certain specific dangers or coercive situations and thus may be somehow understandable as a "natural reaction" from a human and/or political point of view and that they are, to a certain degree, provable because the situation that existed at the time of commission may be reconstructable.

- A second group could be described as situation defences characterized as being essentially dependent on the circumstances of the individual case and/or by the fact that they often contain elements of other defences. This applies in particular to mistake of law, conflict of interests, and obedience to a "superior order". None of these defences is so far recognized without caveat, nor should this happen in the future. Nevertheless, even with war crimes, it is possible to imagine individual situations in which the circumstances, such as an "honest error", a genuine moral conflict, 
or an apparently unavoidable order, indicate that it would be reasonable to exclude punishability .

- A third group is made up of defence strategies that should in principle be denied the power to exclude punishability and should therefore be treated as non-defences: This should apply to the $t u$ quoque argument as well as to an invocation of superior order in terms of the theory of respondeat superior.

3. Finally, one should not forget to note that the whole area of defences requires a much more comprehensive and thorough elaboration than has been offered thus far and that cannot be rendered within the scope of this article. Such basic research requires that particular attention be paid to the following questions:

- The observation that the traditional defences are a rather unstructured conglomerate assembled from different legal traditions, with substantive as well as conceptual frictions is due in part to the differences between continental-European and common law approaches. These differences must be analyzed and understood both in their rationales and in their consequences before they can be overcome by an act of political will.

- To reach this goal, it will be necessary to clarify possibly differing exonerating effects of defences and their structural-systematic classification and rank within the concept of crime. As long as we are not certain whether defences justify, merely excuse, or perhaps exonerate in another way, it appears impossible to adequately comprehend and categorize them.

- Yet another problem, specific to war crimes, is the question of whether justifications and excuses, that are recognized without reservation for everyday crimes and which, perhaps, also apply to international war crimes, may be invoked if this results in the non-punishment of war crimes. This question, too, is still far from being clarified.

The purpose of this article will have been fully achieved if it conveys at least some insight and provides some incentive to delve a little deeper in this field than has been done so far. 